\title{
Käsikirjoituksesta tieteelliseksi artikkeliksi
}

\author{
Sari Torkko
}

MTT, Tutkimuspalvelut, 31600 Jokioinen, sähköposti: sari.torkko@mtt.fi

\section{Monivaiheinen käsikirjoituksen käsittely}

Kirjoittamisen avulla tutkija kertoo tutkimustuloksistaan ja liittyy kansainväliseen tutkijayhteisöön. Tarjottuaan käsikirjoitustaan julkaistavaksi tieteelliseen lehteen tutkijalla on edessä monivaiheinen asiointi lehden toimittajan kanssa. Tämän monivaiheisen käsittelyn aikana käsikirjoituksesta kypsyy tieteellinen artikkeli.

Agricultural and Food Science in Finland -lehden tiedetoimittajana osallistun käsikirjoitusten työstämiseen artikkeleiksi. Käsikirjoitukset käsitellään lehdessämme pääosin samalla tavalla kuin muissakin vertaisarviointia (ns. referee-käytäntö) käyttävissä lehdissä. Omien kokemusten ja kollegojen kertoman perusteella epäilen, että tutkijat eivät tunne käsikirjoitusten käsittelyä riittävän hyvin, koska toimitukseen saapuu keskeneräisiä kirjoituksia ja koska jotkut kirjoittajat eivät hoida osuuttaan käsittelystä asiallisesti.

Kerron tässä esityksessä siitä, mitä käsikirjoituksillenne tapahtuu toimituksissa sillä aikaa kun ne eivät ole käsissänne. On hyvä muistaa, että toimituksissa työskentelee tieteellisiä ja teknisiä toimittajia, jotka kommentoivat kirjoituksia erityisosaamisensa mukaan. Yksinkertaistan esitystä puhumalla aina toimittajasta ja oletan toimittajatyypin selviävän asiayhteydestä. Esittelen käsikirjoituksen vaiheet aikajärjestyksessä eli käsikirjoituksen saapuminen, asiantuntijatarkastus, korjatun käsikirjoituksen saapuminen ja vedoksen tarkastus. Lisäksi kuvaan lyhyesti, mitä kannattaa muistaa toimiessaan asiantuntijatarkastajana. Kirjoitusten julkaisemista voi selkeästi nopeuttaa ja edesauttaa, kun tuntee toimituksen eri vaiheet hyvin. Koska toimimme vakiintuneen kansainvälisen mallin mukaan, käytännöt soveltuvat myös muiden lehtien kanssa asiointiin.

\section{Käsikirjoituksen saapuminen}

Kun kirjoitus saapuu, toimittaja muodostaa siitä tärkeän ensivaikutelman. Tarkasteltavana on tällöin kirjeitse saapunut paperikopio tai sähköisesti vastaanotettu tiedosto. Ensimmäiseksi toimittaja lukee kirjoituksen otsikon, mutta pian huomio kiinnittyy siihen, onko kirjoitus laadittu kirjoitusohjeiden mukaan. Samoin kirjoituksen pituus eli tulosteen paksuus käyvät välittömästi ilmi. Epäsiisti ulkoasu antaa epäilyksen huonosti tehdystä työstä.

Silmäilyn jälkeen toimittaja perehtyy kirjoitukseen huolellisemmin: lukee otsikon uudelleen ja abstraktin. Otsikko ja abstrakti kannattaa ehdottomasti laatia huolella, sillä niitä luetaan enemmän kuin mitään muuta kirjoituksen osaa. Niitä luetaan asiantuntijatarkastajia etsittäessä, tarkastuksessa ja jaettaessa tietoa julkaistusta artikkelista. Abstrakti on käsikirjoitus pienoiskoossa. Näin voidaan todeta hyvässä ja pahassa, sillä kokemusten mukaan puutteellisessa käsikirjoituksessa on puutteellinen abstrakti. Jos johtopäätökset puuttuvat abstraktista, ne puuttuvat usein myös itse käsikirjoituksesta.

Toimittaja lukee myös tutkimuksen tarkoituksen ja selvittää tutkimusaineiston määrän. Näin varmistetaan, että saapunut kirjoitus sopii aiheensa ja laajuutensa puolesta julkaistavaksi lehdessä. Jos kirjoitus ei aiheensa tai aineiston määrän puolesta sovi julkaistavaksi lehdessä, kirjoitus palautetaan kirjoittajille. Saatekirjeessä yleensä suositellaan lehtiä, joihin tuloksia kannattaa tarjota julkaistavaksi, tai pyydetään kirjoittajia tekemään jatkotutkimuksia johtopäätösten oikeutukseksi. Jos kirjoitus sopii julkaistavaksi lehdessä, seuraavaksi tarkastetaan tekniset seikat.

Teknisen tarkastuksen tarkoituksena on varmistaa, että kirjoitus on valmis asiantuntijatarkastukseen. Kirjoittajan ja lehden kannalta on ensiarvoisen tärkeää, että kirjoitusta arvioivat asiantuntijat voivat keskittyä kirjoituksen sisältöön ja täten "antavat parastaan" teknisten seikkojen häiritsemättä. Lisäksi asiantuntijatarkastajat ansaitsevat käsittelyynsä viimeistellyn kirjoituksen, sillä tavallisesti he ovat kiireisiä ja tekevät työtään ilman palkkiota ns. tieteenalansa edistämisen nimissä. Yleensä teknisessä tarkastuksessa kirjoituksesta tarkastetaan kirjoitusohjeiden noudattaminen, otsikko, abstraktin rakenne ja pituus, englannin kieli ja tyyli, taulukot ja kuvat sekä viitteet. Jos jossakin edellä mainituista havaitaan puutteita, kirjoitus palautetaan kirjoittajille viimeistelyä varten.

Jos saapuva käsikirjoitus sopii lehden aihealueeseen, julkaistava aineisto vaikuttaa riittävältä, ja jos kirjoitus läpäisee teknisen tarkastuksen, kirjoitus lähetetään asiantuntijatarkastukseen. Tavallisesti lehdet lähettävät kirjoittajalle tällöin ilmoituksen kirjoituksen saapumisesta, kertovat sen lähteneen tarkastukseen ja antavat arvion tarkastuksen kestosta. 


\section{Asiantuntijatarkastus}

Asiantuntijatarkastuksen tarkoituksena on arvioida julkaistavaksi tarjottu tutkimus ja käsikirjoitus. Kaksi tai useampia riippumattomia asiantuntijoita kertovat mielipiteensä tutkimuksen merkittävyydestä, uutuusarvosta ja kiinnostavuudesta. Arvioijat kommentoivat koesuunnitelman tarkoituksenmukaisuutta, tutkimusmenetelmiä, tulosten tarkastelua ja johtopäätösten oikeellisuutta. Lisäksi he arvioivat itse kirjoitusta, sen selkeyttä, jäsentelyä ja pituutta. Tarkastaessaan kirjoituksen asiantuntijat antavat osaamisensa kirjoittajien hyödynnettäväksi. Kommenttien tarkoituksena on parantaa käsikirjoitusta, mutta toisaalta estää epäonnistuneiden tutkimusten ja väärien johtopäätösten julkaiseminen.

Lehdet pyytävät 2-4 asiantuntijalta lausunnon kirjoituksesta. Tavallisesti tarkastajille annetaan 46 viikkoa aikaa lausunnon tekemiseen. Tarkastajat lähettävät lausuntonsa lehden toimitukseen, ja toimittaja päättää kirjoituksen julkaisemisesta tai hylkäämisestä lausuntojen perusteella. Jos lausunnoissa esitetään kirjoituksen hylkäämistä, toimittaja lähettää hylkäyspäätöksen perusteluineen kirjoittajille. Jos lausunnoissa vaaditaan muutoksia kirjoitukseen, toimittaja lähettää lausunnot ja toimituksen ohjeet kirjoittajille. Toimituksen ohjeissa kerrotaan, mitkä muutoksista täytyy tehdä ja mitä niistä on syytä harkita kirjoitusta muokatessa. Yleensä lausunnoissa vaaditaan muutoksia kirjoitukseen, joten on hyvin harvinaista, että toimittaja lähettää pelkän hyväksymiskirjeen kirjoittajille.

Kirjoittajien on hyvä muistaa, että kirjoitus, jota on pyydetty muokkaamaan ennen julkaisemista, ei ole vielä hyväksytty, mutta ei myöskään hylätty kirjoitus. Kirjoittajien edellytetään tekevän muutokset ennen kirjoituksen julkaisemista, ja muutosten tekemättä jättäminen saattaa aiheuttaa kirjoituksen hylkäämisen. Joskus kirjoittajasta saattaa tuntua siltä, että arvioija on ymmärtänyt väärin käsikirjoituksessa esitetyn asian. Tällöin on syytä selkeyttää asian ilmaisua, sillä jokin käsikirjoituksessa on aiheuttanut väärinymmärryksen. Arvioijan lisäksi myös muut saattavat tulkita ilmaisun väärin. Näin ollen kaikenlaiseen palautteeseen kannattaa suhtautua vakavasti. Monet lehdet pyytävät kirjoittajia kertomaan tekemistään muutoksista erillisellä liitteellä, ja huolellisesti laadittu liite nopeuttaakin korjatun kirjoituksen arviointia.

\section{Korjatun käsikirjoituksen saapuminen}

Kun korjattu kirjoitus saapuu toimitukseen, toimittaja selvittää miten kirjoitus on muuttunut. Tässä työssä luettelo tehdyistä muutoksista tarkastajien kommentteihin viitaten on suureksi avuksi. Tietysti toimittaja myös lukee kirjoituksen uuden version.

Jos kirjoittajat ovat ottaneet arvioijien huomautukset ja parannusehdotukset riittävästi huomioon, kirjoitus hyväksytään julkaistavaksi, ja kirjoituksen valmistelu painatusta tai sähköistä julkaisemista varten aloitetaan. Tässä vaiheessa kirjoittajat voivat kertoa artikkelinsa olevan hyväksytty (in press). Jos toimittaja epäröi tehdä julkaisupäätöstä itse tai jos arvioija on pyytänyt kirjoituksen korjatun version luettavakseen, kirjoitus lähetetään uudelleen samoille asiantuntijoille. Uusi arviointi saattaa merkitä uusia asioita korjattavaksi. Koska arvioinnissa pyritään mahdollisimman hyvään lopputulokseen, myös nämä uudet muutosehdotukset on syytä ottaa huomioon. Jos korjattuun kirjoitukseen ei ole tehty vaadittuja muutoksia, se hylätään. Lausuntojen huomioon ottaminen on edellytys kirjoituksen julkaisemiselle.

\section{Vedoksen tarkastus}

Hyväksytty kirjoitus valmistellaan toimituksessa painatusta tai sähköistä julkaisemista varten. Ennen julkaisemista artikkelin vedos lähetetään kuitenkin kirjoittajille tarkastettavaksi. Nykyään vedos lähetetään sähköpostitse liitetiedostona.

Kirjoittajien tehtävänä on tarkastaa artikkelin sisältö huolellisesti, kun sen sijaan ulkoasu tarkastetaan toimituksessa. Sisältöön ei kuitenkaan saa tehdä suuria, käsikirjoituksesta poikkeavia muutoksia, sillä muutosten aiheuttama taiton muutos maksaa lehden kustantajalle. Monet lehdet laskuttavatkin kirjoittajilta taittoa muuttavat muutokset. Korjaukset tehdään vedokseen selkeästi ja toimituksen pyytämin korjausmerkein. Kirjoittajilta palaava vedos tarkastetaan vielä toimituksessa, sillä vedokseen ehdotetut korjaukset eivät saa muuttaa tarkastajien hyväksymää sisältöä.

Vedos on palautettava toimitukseen muutaman päivän ja enimmillään viikon aikana. Aikataulua tulee noudattaa, sillä artikkelin julkaisemista ei tässä vaiheessa pidä viivästyttää. Monet kustantajat lähettävät vedoksen mukana julkaisuoikeuden siirtosopimuksen allekirjoitettavaksi. Sen sijaan eripainos on usein artikkeli tiedostona. Toimitus palauttaa korjatun vedoksen kirjapainoon tai valmistelee sen sähköisesti julkaistavaksi. 


\section{Asiantuntijatarkastajana toimiminen}

Laadukkaalla tiedelehdellä on hyvä ja toimiva asiantuntijatarkastus. Tästä keskeisestä julkaisemisen vaiheesta hyötyvät kaikki: lukijat selkeinä ja luotettavina artikkeleina, kirjoittajat palautteesta oppineina ja lehti arvioituna sisältönä. Arviota ei pyydetä keneltä tahansa, vaan lausuntoa pyydetään kirjoituksen tutkimusalan hyviltä asiantuntijoilta. Siksi tutkijan tulee tässä vastuullisessa roolissa toimiessaan muistaa muutama ominaisuus: luottamuksellisuus, objektiivisuus, perusteleminen ja aikataulussa pysyminen. Arvioijat pysyvät yleensä kirjoittajille nimettöminä.

Tarkastuksen aikana käsikirjoituksen tiedot ovat luottamuksellisia, ja ne ovat kirjoittajien yksityisomaisuutta, kunnes ne on julkaistu. Niinpä tarkastajan ei tule keskustella käsikirjoituksen asioista kenenkään muun kuin lausunnon pyytäneen toimittajan kanssa. Kirjoitusta ei tule luovuttaa kollegalle tarkastettavaksi ilman toimittajan lupaa. Lisäksi kirjoituksen aineisto tulee palauttaa toimittajalle lausunnon mukana.

Tarkastajan tulee lukea kirjoitus huolellisesti ja objektiivisesti. Hyvät kommentit ovat perusteltuja ja riittävän yksityiskohtaisia. Kommenttien tarkoituksena on auttaa kirjoittajia parantamaan käsikirjoitusta. Esimerkiksi pelkkä toteaminen "tulosten tarkastelu on liian pitkä" on hyvä korvata osoittamalla mitkä osat tekstistä tulisi lyhentää tai poistaa. Kirjoittajille tulee antaa sellaisia ohjeita, joita toivoisit omalle kirjoituksellesi. Monet lehdet lähettävät käsikirjoituksen mukana arviointilomakkeen tai ohjeen, jonka noudattaminen on suotavaa. Sivu- ja rivinumeroviittaukset muutoksia vaativiin kohtiin auttavat kirjoittajia.

Kommentit tulee lähettää toimitukseen sovittuun määräpäivään mennessä. Ellei määräaikaa ole erikseen sovittu, toimitus odottaa lausuntoasi 4-6 viikon aikana. Palauta kirjoitus heti takaisin toimitukseen, jos arvioit lausuntosi vaativan pidemmän ajan. Muista kertoa yllättävistä viivytyksistä lausuntoa pyytäneelle toimittajalle.

\section{Kirjoitus nopeammin artikkeliksi}

Tarjottuaan käsikirjoitustaan julkaistavaksi tieteelliseen lehteen tutkijalla on edessään monivaiheinen asiointi lehden toimittajan kanssa: käsikirjoituksen tarjoaminen julkaistavaksi, asiantuntijatarkastus, korjatun käsikirjoituksen muokkaaminen ja vedoksen tarkastus. Käsikirjoitus kypsyy artikkeliksi nopeasti, jos kaikki osapuolet tekevät vuorollaan parhaansa. Omaa osuuttaan ei missään vaiheessa saa jättää puolitiehen ja luottaa, että kyllä asian ehtii myöhemmin vielä korjata tai että joku muu sen korjaa. Jokainen "periksi anto" tai "luovutus" kostautuu myöhemmissä julkaisemisen vaiheissa ja myöhästyttää kirjoituksen julkaisemista.

Tutustu huolellisesti lehden julkaisuperiaatteisiin varmistaaksesi käsikirjoituksesi sopivuuden lehteen. Laadi kirjoitukselle hyvä otsikko ja rakenteinen abstrakti, sekä viimeistele kirjoituksen taulukot ja kaaviot huolella. Noudata kirjoitusohjeita viimeistelyssä ja lähetä oikea määrä kopioita oikeassa muodossa toimitukseen. Näin varmistat kirjoituksen etenemisen suoraan asiantuntijatarkastukseen. Suhtaudu asiantuntijoiden palautteeseen rakentavasti ja tee vaaditut muutokset. Lisäksi toimi aikataulujen mukaan korjauksia tehdessä ja vedosta tarkastaessa. Näin toimien nopeutat ja edesautat käsikirjoituksesi julkaisemista. 